\title{
The Potential Role of Hydrogen Sulfide in the Regulation of Cerebrovascular Tone
}

\author{
Eleni Dongó ${ }^{1,2}$ (D) and Levente Kiss ${ }^{1, * \mathbb{D}}$ \\ 1 Department of Physiology, Semmelweis University, 1088 Budapest, Hungary \\ 2 Department of Neurology, Semmelweis University, 1088 Budapest, Hungary; \\ dongo.eleni@med.semmelweis-univ.hu \\ * Correspondence: kiss.levente@med.semmelweis-univ.hu; Tel.: +36-20-384-5753
}

Received: 31 October 2020; Accepted: 14 December 2020; Published: 16 December 2020

\begin{abstract}
A better understanding of the regulation of cerebrovascular circulation is of great importance because stroke and other cerebrovascular diseases represent a major concern in healthcare leading to millions of deaths yearly. The circulation of the central nervous system is regulated in a highly complex manner involving many local factors and hydrogen sulfide $\left(\mathrm{H}_{2} \mathrm{~S}\right)$ is emerging as one such possible factor. Several lines of evidence support that $\mathrm{H}_{2} \mathrm{~S}$ takes part in the regulation of vascular tone. Examinations using either exogenous treatment with $\mathrm{H}_{2} \mathrm{~S}$ donor molecules or alterations to the enzymes that are endogenously producing this molecule revealed numerous important findings about its physiological and pathophysiological role. The great majority of these studies were performed on vessel segments derived from the systemic circulation but there are important observations made using cerebral vessels as well. The findings of these experimental works indicate that $\mathrm{H}_{2} \mathrm{~S}$ is having a complex, pleiotropic effect on the vascular wall not only in the systemic circulation but in the cerebrovascular region as well. In this review, we summarize the most important experimental findings related to the potential role of $\mathrm{H}_{2} \mathrm{~S}$ in the cerebral circulation.
\end{abstract}

Keywords: hydrogen sulfide; cerebral circulation; gasotransmitters

\section{Introduction}

Cases of ischemic and hemorrhagic stroke represent leading causes of death as these are responsible for nearly 6 million deaths/year globally [1]. The major effect of these diseases on the healthcare system and on the community is also underlined by the number of chronic disability cases that are caused by them [2]. Subarachnoideal bleeding is another severe condition where not only the bleeding itself but the consequential vasospasm constitutes a problem [3]. In addition to these life-threatening diseases a division of primary headaches (cluster headache, migraine) are also accompanied with vascular malfunction [4,5]. Thus, a large number of cerebrovascular diseases [6] underline the importance of better understanding of cerebrovascular regulation and achievements in this field may have great clinical impact.

\section{Factors Regulating Cerebrovascular Tone}

The circulation of the central nervous system is regulated in a complex manner and it is mainly controlled by local factors while the neural control, that is so critical in the systemic circulation, is relatively weak and even controversial in the cerebral circulation [7-9]. The local factors involve several mechanisms such as myogenic, flow or shear mediated and metabolic responses which were concisely reviewed recently [10] and only a brief summary is provided here. It is important to emphasize that the autoregulation of blood flow in the intracranial space is of great importance, and this is thought to be the result of a multi-factorial complex mechanism which involves myogenic response, 
shear stress, hyper- and hypocapnia and hypoxia as well [9,11,12]. The range of autoregulation in physiological circumstances is between $50 \mathrm{mmHg}$ and $150 \mathrm{mmHg}$ mean arterial pressure in the systemic circulation [9]. The coupling of blood flow to metabolism provides the necessary local changes in brain circulation for the actual neuronal activity. Rising local $\mathrm{CO}_{2}$ level efficiently increases cerebral blood flow through vasodilation, while lowered $\mathrm{PaCO}_{2}$ decreases blood flow through increased arterial resistance via the alteration of perivascular $\mathrm{pH}$ [13]. Vasoactive substances like $\mathrm{H}^{+}$and $\mathrm{K}^{+}$ are also released in case of low cerebral blood flow causing vasodilation $[9,13]$. Neurotransmitters and neuromodulators (such as acethylcholine, catecholamines, neuropeptides) induce $\mathrm{Ca}^{2+}$-waves in the adjacent astrocytes and neuronal dendrites resulting in the release of further vasoactive molecules such as nitric oxide (NO, the formerly known EDRF) and/or arachidonic acid metabolites [9,13-15].

\section{Gasotransmitters in Cerebral Circulation}

The first identified gasotransmitter molecule in the mammalian circulation was NO [16] which was shown to increase cerebral blood flow by decreasing vascular resistance in the cerebral vessels similarly to its effects in the systemic circulation [17]. NO in the central nervous system may originate from endothelial cells (produced by endothelial NOS, eNOS), from autonomic nitrergic nerve endings or from neurons of the central nervous system (produced by neuronal nitric oxide synthase, nNOS), or by the inducible isoform of the enzyme (iNOS) $[17,18]$. Decreased availability of NO is known to be a triggering factor of vasospasm after subarachnoid hemorrhage, whereas overproduction through iNOS occurs during inflammation or cerebral ischemia [18]. Several evidences provided by experiments involving animals indicate that the NOS enzyme contributes to the neurovascular coupling (known as functional hyperemia) and a recent study demonstrated this in humans as well [15,19]. However, it is still under debate if NO had a role in hypercapnia-induced vasodilation [17].

Subsequently, it was realized that not only NO but other endogenously produced molecules such as carbon monoxide (CO) can also play a role in the regulation of cerebrovascular system [20]. Endogenously produced $\mathrm{CO}$ originates from the metalloprotein heme by its synthesizing enzyme, heme oxygenase (HO), which has two distinct isoforms, the inducible $\mathrm{HO}-1$ and the constitutive $\mathrm{HO}-2[18,21]$. The production of $\mathrm{CO}$ in the central nervous system takes place in the cerebral vascular cells, neurons and glial cells by $\mathrm{HO}-2$, which has the highest concentration in the brain [22]. $\mathrm{CO}$ in the central nervous system influences neuronal activity, affects local regulation of cerebral circulation and supports antioxidant defense [22]. The vasodilatative effect of $\mathrm{CO}$ was proven by several studies $[21,23,24]$. The mechanism behind the vasodilation includes the activation of $\mathrm{K}_{\mathrm{ATP}}$-channels and the cGMP pathway seems to be also affected [18]. Furthermore, CO-induced vasodilation occurs through activation of $\mathrm{K}_{\mathrm{Ca}}$ channels, and $\mathrm{HO}$ is also presumably involved in hypoxic cerebrovascular dilatation [21,23-25]. It should be also noted that some studies reported vasoconstriction after $\mathrm{CO}$ treatment, probably through the inhibition of NOS [22]. According to these results, $\mathrm{CO}$ derived from HO-2 may serve as a tonic vasoregulator antagonizing NO-mediated vasodilation in the rat cerebral microcirculation [26]. Furthermore, through elevation of cGMP levels, NO can inhibit directly and activate indirectly the HO-2 isoform [22]. Taken into account these interactions, a quite complex feedback control is probable [22].

Importantly, among the many small molecules (such as hydrogen peroxide and potassium ion) that were implicated as potentially having important roles in the vasoactivity of cerebral vessels, hydrogen sulfide, the "third gasotransmitter" is also present [18,27-30].

\section{Hydrogen Sulfide as the Third Gasotransmitter}

There is emerging knowledge about $\mathrm{H}_{2} \mathrm{~S}$ as an endogenously produced molecule with several effects in the living organisms, therefore it can be considered as the third gasotransmitter. $\mathrm{H}_{2} \mathrm{~S}$ is a water-soluble, colorless, flammable gas and a weak acid which is mainly dissociated (approx. in 80\%) to hydrosulfide anions $\left(\mathrm{HS}^{-}\right)$and hydrogen ions $\left(\mathrm{H}^{+}\right)$at physiological $\mathrm{pH}$ and body temperature [31]. Four enzymatic pathways are responsible for the enzymatic production of hydrogen sulfide in 
the human body. In the cardiovascular system, cystathionine-gamma-lyase (CSE) produces the majority of endogenous $\mathrm{H}_{2} \mathrm{~S}$ which has a role in the regulation of vascular tone and angiogenesis and may have cardioprotective potential as well [32]. In the nervous system, cystathionine beta-synthase (CBS) is the main $\mathrm{H}_{2} \mathrm{~S}$ producing enzyme and it is localized in astrocytes but CBS was detected in neuronal stem cells as well $[33,34]$. Roles of CBS could potentially involve protection of the endothelial function by anti-inflammatory, antioxidant and pro-angiogenic effects [35]. Both enzymes use pyridoxal-5-phosphate (PLP) as a cofactor [36]. 3-mercaptopyruvate-sulfurtransferase (MST) and cysteine amino-transferase (CAT) represent the third enzymatic pathway producing $\mathrm{H}_{2} \mathrm{~S}$ in various cell types (endothelial cell, vascular smooth muscle cells, cerebellar Purkinje-cells) [34]. A recently discovered fourth enzyme, the D-amino acid oxidase (DAO), uses D-cysteine to produce $\mathrm{H}_{2} \mathrm{~S}$ and this pathway occurs mainly in the kidney and in the cerebellum [37]. Furthermore, non-enzymatic processes that produce $\mathrm{H}_{2} \mathrm{~S}$ from elementar sulfur can be found in erythrocytes and gut bacteria [31]. However, it is important to note that although the details of endogenous $\mathrm{H}_{2} \mathrm{~S}$ production are fairly well-known, the precise measurement of the $\mathrm{H}_{2} \mathrm{~S}$ levels in biological samples is still a challenge, due to the volatile character of $\mathrm{H}_{2} \mathrm{~S}$ and its extensive interactions with other compounds [38].

As a result of its widespread effects under physiological and pathophysiological circumstances, the examinations regarding the actions of $\mathrm{H}_{2} \mathrm{~S}$ on the vascular system are of great interest [39-44]. Based on multiple studies the three main mechanisms behind the biological effects of $\mathrm{H}_{2} \mathrm{~S}$ are: (1) persulfidation/polysulfide generation, (2) interaction with reactive oxygen and nitrogen species and (3) reaction with metalloproteins [36]. Persulfidation is a post-translational modification where a thiol group is added to a specific cysteine residue of a protein (enzymes, ion channels, etc.), resulting in increased or blocked biological activity [36,45]. We have concisely reviewed the possible consequences of these mechanisms on the regulation of the vascular tone in our recent review [36].

Considering the interactions of $\mathrm{H}_{2} \mathrm{~S}$ with other gasotransmitters many such possibilities can be mentioned. $\mathrm{H}_{2} \mathrm{~S}$ and $\mathrm{NO}$ has synergistic effect on the vasodilation of rat pial arteries. The effect of $\mathrm{H}_{2} \mathrm{~S}$ seems to be more pronounced in smaller (diameter being less than $20 \mu \mathrm{M}$ ) arteries while the NO-mediated vasodilation has bigger role in larger arteries [46]. $\mathrm{H}_{2} \mathrm{~S}$ induces vasodilation through interaction with the NO-sGC-cGMP-PKG pathway $[40,46]$. There are several major $\mathrm{H}_{2} \mathrm{~S}-\mathrm{NO}$ common products as well such as nitrosopersulfide (SSNO-), polysulfides and dinitrososulfite [N-nitrosohydroxylamine-N-sulfonate (SULFI/NO)] each with distinct biological effects [47]. One of the best known NO- $\mathrm{H}_{2} \mathrm{~S}$ common molecule, nitroxyl (HNO), is formed from SULFI/NO and is proven to have its own effect on the vascular tone [47]. Additionally, the $\mathrm{H}_{2} \mathrm{~S}-\mathrm{NO}$ crosstalk in meningeal arteries induces vasodilation through the activation of the HNO-TRPA1-CGRP pathway [4]. Considering another gasotransmitter, studies in mice revealed that $\mathrm{CO}$ produced from HO-2 constitutively inhibits CBS in normoxic circumstances, but in the case of hypoxia, $C O$ level drops and CBS is able to generate $\mathrm{H}_{2} \mathrm{~S}$ finally resulting in vasodilation [48]. According to the results, this interaction between $\mathrm{CO}$ and $\mathrm{H}_{2} \mathrm{~S}$ is supposed to be relevant under physiological conditions [48]. In this context, it is noteworthy that in another study (made on newborn pigs) CSE did not play a role in hypoxic vasodilation [49].

\section{Experiments on the Involvement of $\mathrm{H}_{2} \mathrm{~S}$ in the Cerebrovascular System}

There are several possible avenues in investigating the vasoactive functions of $\mathrm{H}_{2} \mathrm{~S}$ in the cerebrovascular system. Regarding the used methods the majority of research on cerebral circulation is done by wire myography [50-53] pressure myography [54,55] or both [56]. Patch-clamp techniques are also frequently used [54-56]. A peculiar approach, the surgically created cranial window allows repeated in vivo examinations in the same animal [49] while histological studies and stainings help to identify the characteristic enzyme type of a distinct tissue sample [3]. Regarding the concepts of the studies one possible and widely used option is to examine the effects at a higher $\mathrm{H}_{2} \mathrm{~S}$ level than the endogenously produced amount. In this case, the following two methods are used the most often: (1) administration of L-cysteine, which is the universal substrate of the producing enzymes; (2) administration of pure $\mathrm{H}_{2} \mathrm{~S}$ gas or $\mathrm{H}_{2} \mathrm{~S}$ donor molecules. Considering the method of $\mathrm{H}_{2} \mathrm{~S}$-administration several 
possible routes are used in experiments involving animals. In vivo studies are using many times intraperitoneal $[3,57,58]$ administration or-in cerebrovascular studies-intraventricular injection [58] and even topical treatment through a previously prepared cranial window [46]. In human studies involving cerebrovascular questions, exogenous $\mathrm{H}_{2} \mathrm{~S}$ treatment was not performed, only serum cysteine level was measured in a study including post-stroke patients [58]. However, intravenous administration was performed in certain studies exploring the role of $\mathrm{H}_{2} \mathrm{~S}$ on systemic circulation [47,59].

Experiments and their major conclusions using $\mathrm{H}_{2} \mathrm{~S}$ donor treatments in in vitro, ex vivo and in vivo settings are summarized in Tables $1-3$, respectively.

Table 1. In vitro investigations involving $\mathrm{H}_{2} \mathrm{~S}$ donor treatment.

\begin{tabular}{|c|c|c|c|}
\hline Study Type & Experimental Situations & Major Conclusions & Ref \\
\hline $\begin{array}{l}\text { Cell culture studies on } \\
\text { mouse brain endothelial } \\
\text { cells (MBECs) and type I. } \\
\text { clone astrocytes }\end{array}$ & $\begin{array}{c}5 \mu \mathrm{M} \text { NaHS treatment for } \\
\text { 0-20-60-180 min during } \\
\text { oxygen-glucose deprivation, or } \\
\text { incubation of MBECs with } 5 \mu \mathrm{M} \\
\text { NaHS and the PI3K inhibitor } \\
\text { LY294002 in a wound } \\
\text { healing assay }\end{array}$ & $\begin{array}{l}\text { NaHS treatment increased VEGF, } \\
\text { angiotensin-1 (Ang-1) expression } \\
\text { during oxygen-glucose } \\
\text { deprivation and also increased } \\
\text { endothelial cell migration } \\
\text { and tube formation }\end{array}$ & {$[57]$} \\
\hline $\begin{array}{c}\text { Study on } \\
\text { Sprague-Dawley rats } \\
\text { with Western blot } \\
\text { and immunofluorescent } \\
\text { staining and TUNEL } \\
\text { assay on brain sections }\end{array}$ & $\begin{array}{l}\text { Middle cerebral artery occlusion } \\
\text { with } 120 \mathrm{~min} \text { ischemia followed } \\
\text { by reperfusion. } 5 \mathrm{mg} / \mathrm{kg} \text { ip. NaHS } \\
\text { treatment from the } 3 \mathrm{rd} \text { to the } 14 \text { th } \\
\text { day after reperfusion. }\end{array}$ & $\begin{array}{l}\text { NaHS treatment resulted in } \\
\text { augmented angiogenesis in } \\
\text { the peri-infarct area; improved } \\
\text { functional outcomes; } \\
\text { phosphorylation of AKT and ERK } \\
\text { increased; VEGF, Ang-1 } \\
\text { expression also increased }\end{array}$ & [57] \\
\hline $\begin{array}{l}\text { Patch clamp study on } \\
\text { single myocytes from } \\
\text { isolated rat cerebral } \\
\text { artery }\end{array}$ & $\begin{array}{l}\text { Effects of } 1-10 \mathrm{mM} \text { NaHS on } \\
\text { L-type } \mathrm{Ca}^{2+} \text {-currents }\end{array}$ & $\begin{array}{l}\text { NaHS dose-dependently inhibited } \\
\text { L-type } \mathrm{Ca}^{2+} \text {-currents }\end{array}$ & [56] \\
\hline $\begin{array}{c}\text { Patch clamp study on } \\
\text { isolated arteriole derived } \\
\text { smooth muscle cells from } \\
\text { newborn piglets }\end{array}$ & $\begin{array}{l}\text { Effects of } 10 \mu \mathrm{M} \mathrm{Na}{ }_{2} \mathrm{~S} \\
\text { on } \mathrm{K}_{\mathrm{Ca}} \text { currents }\end{array}$ & $\begin{array}{c}\mathrm{H}_{2} \mathrm{~S} \text { increased } \mathrm{K}_{\mathrm{Ca}} \text { current } \\
\text { frequency, but did not affect } \\
\text { the amplitude; the treatment had } \\
\text { no effect directly on the } \mathrm{K}_{\mathrm{Ca}} \\
\text { channels but only on } \mathrm{Ca}^{2+} \text { sparks }\end{array}$ & [55] \\
\hline $\begin{array}{l}\text { Patch clamp study on } \\
\text { cells from pial arteries } \\
\text { from newborn piglets }\end{array}$ & $\begin{array}{c}\text { Measurement of } \mathrm{K}^{+} \text {-currents after } \\
\text { pinacidil, } 10 \mu \mathrm{M} \mathrm{Na}{ }_{2} \mathrm{~S} \text { or } 20 \mu \mathrm{M} \\
\text { NaHS treatment, and studying } \\
\text { the effect of glibenclamide }\left(\mathrm{K}_{\mathrm{ATP}}\right. \\
\text { inhibitor) }\end{array}$ & $\begin{array}{c}\text { Pinacidil, } \mathrm{Na}_{2} \mathrm{~S} \text { and } \mathrm{NaHS} \\
\text { induced } \mathrm{K}^{+} \text {-currents through } \\
\mathrm{K}_{\text {ATP }} \text { channels. Glibenclamide } \\
\text { fully reversed the effect of } \\
\text { pinacidil, and partially reversed } \\
\text { the effect of } \mathrm{H}_{2} \mathrm{~S} \text {-donors }\end{array}$ & [54] \\
\hline $\begin{array}{l}\text { Study on basilar arteries } \\
\text { after experimental } \\
\text { subarachnoid } \\
\text { hemorrhage (SAH) in } \\
\text { Wistar rats }\end{array}$ & $\begin{array}{l}\text { Measurement of CBS and CSE } \\
\text { expression after } 0.18 \mathrm{mmol} / \mathrm{kg} \\
\text { NaHS ip. treatment }\end{array}$ & $\begin{array}{l}\text { NaHS increased CBS expression in } \\
\text { both the control and SAH groups; } \\
\text { CSE expression did not change } \\
\text { between groups }\end{array}$ & [3] \\
\hline $\begin{array}{l}\text { Study with cAMP level } \\
\text { immunoassay } \\
\text { and adenylyl cyclase } \\
\text { activity assay on human } \\
\text { brain vascular smooth } \\
\text { muscle cells (HBVSMCs) }\end{array}$ & $\begin{array}{l}\text { Measurement of cAMP level after } \\
10^{-4} \mathrm{M} \text { NaHS treatment, } \\
\text { isoprenaline } \\
\text { and forskolin treatment }\end{array}$ & $\begin{array}{l}\text { NaHS attenuated the elevated } \\
\text { cAMP levels after isoprenaline } \\
\text { treatment; also attenuated } \\
\text { the enhanced adenylyl cyclase } \\
\text { activity after forskolin }\end{array}$ & {$[50]$} \\
\hline
\end{tabular}


Table 2. Ex vivo investigations involving $\mathrm{H}_{2} \mathrm{~S}$ donor treatment.

\begin{tabular}{|c|c|c|c|}
\hline Study Type & Experimental Situations & Major Conclusions & Ref \\
\hline \multirow{4}{*}{$\begin{array}{l}\text { Wire myograph study on basilar } \\
\text { artery segments from } \\
\text { Sprague-Dawley rats }\end{array}$} & $\begin{array}{c}\text { Effects of } 10^{-7}-10^{-3.5} \mathrm{M} \\
\mathrm{NaHS}, \mathrm{Na}_{2} \mathrm{~S}, \mathrm{GYY} 4137 \text { on basilar } \\
\text { artery segments }\end{array}$ & $\begin{array}{l}\text { NaHS induced dose-dependent } \\
\text { vasoconstriction; the effect } \\
\text { decreased at } 10^{-3.5} \mathrm{M} \\
\text { concentration. NaHS had } \\
\text { the highest contractile potency, } \\
\text { followed by } \mathrm{Na}_{2} \mathrm{~S} \text { and GYY } 4137 \\
\text { had a low contractile potency }\end{array}$ & \multirow[t]{4}{*}{50} \\
\hline & $\begin{array}{c}\text { effects of } \mathrm{NaHS} \text {, given at } \\
\text { the same time/after isoprenaline } \\
\text { or forskolin treatment }\end{array}$ & $\begin{array}{l}\text { If isoprenaline or forskolin was } \\
\text { given after NaHS } \\
\text { the vasocontriction was } \\
\text { augmented. When NaHS } \\
\text { and isoprenaline/forskolin were } \\
\text { given together, the vasorelaxant } \\
\text { effect of isoprenaline decreased. }\end{array}$ & \\
\hline & $\begin{array}{c}\text { effects of NaHS given with } \\
\text { 8B-cAMP (analog of cAMP) } \\
\text { and Bay K-8644 (selective L-type } \\
\mathrm{Ca}^{2+} \text {-channel blocker) }\end{array}$ & $\begin{array}{c}\text { In the presence of 8B-cAMP, } \\
\text { the vasocontriction was } \\
\text { diminished; Bay K-8644 had } \\
\text { no effect }\end{array}$ & \\
\hline & $\begin{array}{l}\text { NaHS treatment on } \\
\text { endothelium-denuded segments } \\
\text { or in the presence of L-NAME }\end{array}$ & $\begin{array}{l}\text { Endothelium removal or } \\
\text { L-NAME enhanced } \\
\text { the NaHS-induced } \\
\text { vasoconstriction }\end{array}$ & \\
\hline \multirow{3}{*}{$\begin{array}{l}\text { Wire myograph study on middle } \\
\text { cerebral artery segments of } \\
\text { Sprague-Dawley rats }\end{array}$} & $\begin{array}{l}\text { Effects of } 10 \mathrm{mM} \text { L-cysteine on } \\
\text { the vascular tone; }\end{array}$ & $\begin{array}{l}\text { L-cysteine dilated the artery } \\
\text { segments }\end{array}$ & \multirow{3}{*}{ [56] } \\
\hline & $\begin{array}{l}\text { Effects of 0.5-1-10 mM NaHS on } \\
\mathrm{CaCl}_{2} \text {-induced contraction }\end{array}$ & $\begin{array}{l}\text { NaHS inhibited } \\
\text { the } \mathrm{CaCl}_{2} \text {-induced contractions }\end{array}$ & \\
\hline & $\begin{array}{l}\text { 0.03-10 mM NaHS treatment } \\
\text { with } \mathrm{K}^{+} \text {-channel blockers } \\
\text { (glibenclamide, TEA, } \\
\text { 4-aminopyridine, } \mathrm{BaCl}_{2} \text { ), with } \\
\text { nifedipine, L-NAME or with } \\
\text { indomethacin }\end{array}$ & $\begin{array}{l}\text { NaHS caused dose-dependent } \\
\text { relaxation, which was unaffected } \\
\text { by the } \mathrm{K}^{+} \text {-channel blockers, } \\
\text { L-NAME or indomethacin, but } \\
\text { its effect was decreased by } \\
\text { nifedipine }\end{array}$ & \\
\hline $\begin{array}{l}\text { Wire myograph study on mouse } \\
\text { basilar arteries }\end{array}$ & $\begin{array}{c}\text { Effects of } 10^{-6}-10^{-3} \mathrm{M} \text { NaHS on } \\
\text { vascular tone given with } \\
\text { LY27632 ROCK inhibitor }\end{array}$ & $\begin{array}{c}\mathrm{H}_{2} \mathrm{~S} \text { induced } \\
\text { concentration-dependent } \\
\text { relaxation; it was attenuated by } \\
\text { LY27632 }\end{array}$ & [53] \\
\hline \multirow{2}{*}{$\begin{array}{l}\text { Wire myograph study on middle } \\
\text { cerebral artery segments of } \\
\text { Sprague-Dawley rats (WT } \\
\text { and STZ-induced diabetic) }\end{array}$} & $\begin{array}{c}\text { Measurements after } 10 \mu \mathrm{M}-100 \\
\text { mM L-cysteine treatment }\end{array}$ & $\begin{array}{c}\text { L-cysteine induced } \\
\text { vasorelaxation in both groups, } \\
\text { but the effect was enhanced in } \\
\text { the diabetic group }\end{array}$ & [52] \\
\hline & $\begin{array}{l}\text { Measurements with } 10 \mu \mathrm{M}-3 \\
\mathrm{mM} \text { NaHS using } \mathrm{KCl} \text {, DIDS, } \\
\text { nifedipine }\end{array}$ & $\begin{array}{l}\mathrm{NaHS} \text { induced equal } \\
\text { vasorelaxation both in } \\
\text { the diabetic and the normal } \\
\text { group; the contribution of } \mathrm{Cl}^{-} \\
\text {channels were less in } \\
\text { the diabetic group }\end{array}$ & \\
\hline \multirow[t]{2}{*}{$\begin{array}{l}\text { Wire myograph study on middle } \\
\text { cerebral artery segments from } \\
\text { Sprague-Dawley rats }\end{array}$} & $\begin{array}{l}\text { Measurements with } 100 \mu \mathrm{M}-3 \\
\text { mM NaHS on intact and on } \\
\text { endothelium-denuded vessel } \\
\text { segments treated with } \\
\text { nifedipine, } \mathrm{K}_{\mathrm{ATP}}, \mathrm{K}_{\mathrm{Ca}}, \mathrm{K}_{\mathrm{V}}, \mathrm{K}_{\mathrm{ir}} \\
\text { blockers }\end{array}$ & $\begin{array}{c}\text { NaHS induced } \\
\text { concentration-dependent } \\
\text { relaxation unaffected by } \\
\text { endothelium removal; } \\
\text { nifedipine and high }\left[\mathrm{K}^{+}\right]_{\mathrm{EC}} \\
\text { decreased the relaxing effect, but } \\
\text { blockers of } \mathrm{K}_{\mathrm{ATP}}, \mathrm{K}_{\mathrm{Ca}}, \mathrm{K}_{\mathrm{V}}, \mathrm{K}_{\mathrm{ir}} \\
\text { channels had no effect. }\end{array}$ & \multirow[t]{2}{*}{ [51] } \\
\hline & $\begin{array}{l}\text { Measurements with } 100 \mu \mathrm{M}-3 \\
\text { mM NaHS using DIDS }\end{array}$ & $\begin{array}{c}\text { DIDS caused significant } \\
\text { rightward shift in } \\
\text { the concentration-response } \\
\text { curve; but not by inhibition of } \\
\mathrm{Cl}^{-} \text {channels or } \mathrm{Cl}^{-} / \mathrm{HCO}_{3}^{-} \\
\text {exchange }\end{array}$ & \\
\hline
\end{tabular}


Table 2. Cont.

\begin{tabular}{|c|c|c|c|}
\hline Study Type & Experimental Situations & Major Conclusions & Ref \\
\hline \multirow{2}{*}{$\begin{array}{l}\text { Pressure myograph study } \\
\text { and confocal imaging on middle } \\
\text { cerebral artery segments from } \\
\text { Sprague-Dawley rats }\end{array}$} & $\begin{array}{l}\text { Effects of } 100 \mu \mathrm{M}-10 \mathrm{mM} \text { NaHS } \\
\text { on myogenic tone }\end{array}$ & NaHS reduced myogenic tone & \multirow[t]{2}{*}{ [56] } \\
\hline & $\begin{array}{c}\text { Effects of } 0.1-0.5-1 \mathrm{mM} \text { NaHS on } \\
{\left[\mathrm{Ca}^{2+}\right]_{\mathrm{i}} \text { level }}\end{array}$ & $\mathrm{NaHS}$ decreased $\left[\mathrm{Ca}^{2+}\right]_{\mathrm{i}}$ & \\
\hline \multirow{3}{*}{$\begin{array}{l}\text { Pressure myograph study } \\
\text { and confocal imaging on cerebral } \\
\text { arterioles from newborn piglets }\end{array}$} & $\begin{array}{c}\text { Effects of iberiotoxin on } 10 \mu \mathrm{M} \\
\mathrm{Na}_{2} \mathrm{~S} \text { induced } \\
\text { hyperpolarization; }\end{array}$ & $\begin{array}{c}\mathrm{H}_{2} \mathrm{~S} \text { induces } \\
\text { iberiotoxin-sensitive } \\
\text { hyperpolarization }\end{array}$ & \multirow[t]{3}{*}{ [55] } \\
\hline & $\begin{array}{l}\text { Effects of } 10 \mu \mathrm{M} \mathrm{Na} \mathrm{N}_{2} \mathrm{~S} \text { alone/with } \\
\text { iberiotoxin or ryanodine }\end{array}$ & $\begin{array}{l}\mathrm{H}_{2} \mathrm{~S} \text { induced vasodilation; it was } \\
\text { partially reversed by } \\
\text { iberiotoxine and also partially } \\
\text { reversed by ryanodine }\end{array}$ & \\
\hline & $\begin{array}{c}\text { Effects of } 10 \mu \mathrm{M} \mathrm{Na}_{2} \mathrm{~S} \text { on } \mathrm{Ca}^{2+} \\
\text { signals }\end{array}$ & $\begin{array}{c}\mathrm{H}_{2} \mathrm{~S} \text { increased } \mathrm{Ca}^{2+}-\text { spark } \\
\text { frequency, decreased }\left[\mathrm{Ca}^{2+}\right]_{\mathrm{IC}} \\
\text { levels and increased } \\
\text { caffeine-induced }\left[\mathrm{Ca}^{2+}\right]_{\mathrm{IC}} \\
\text { transients; elevated }\left[\mathrm{Ca}^{2+}\right]_{\mathrm{SR}} \\
\text { transients }\end{array}$ & \\
\hline $\begin{array}{l}\text { Pressure myograph study on pial } \\
\text { arterioles of newborn piglets }\end{array}$ & $\begin{array}{l}\text { Measurements of vascular } \\
\text { response to } 0.1-1000 \mu \mathrm{M} \mathrm{Na}_{2} \mathrm{~S} \\
\text { and after glibenclamide }\end{array}$ & $\begin{array}{l}\mathrm{H}_{2} \mathrm{~S} \text { induced vasodilation, } \\
\text { which was attenuated by } \\
\text { glibenclamide }\end{array}$ & [54] \\
\hline $\begin{array}{l}\text { Pressure myograph study on } \\
\text { posterior cerebral and cerebellar } \\
\text { arteries of wild-type } \\
\text { and SUR2-null mice }\end{array}$ & $\begin{array}{l}\text { Measurements of vascular } \\
\text { response to } 5 \mu \mathrm{M} \mathrm{Na}_{2} \mathrm{~S} \\
\text { and pinacidil in WT } \\
\text { and SUR2-null animals }\end{array}$ & $\begin{array}{l}\mathrm{Na}_{2} \mathrm{~S}-\text { and pinacidil-induced } \\
\text { vasodilation was attenuated in } \\
\text { the SUR2-null mice }\end{array}$ & [54] \\
\hline $\begin{array}{c}\text { Study on basilar arteries after } \\
\text { subarachnoid hemorrhage (SAH) } \\
\text { in Wistar rats }\end{array}$ & $\begin{array}{c}\text { Effects of } 0.18 \mathrm{mmol} / \mathrm{kg} \mathrm{NaHS} \text { ip. } \\
\text { on luminal diameter and wall } \\
\text { thickness }\end{array}$ & $\begin{array}{l}\text { NaHS had a vasodilatory effect, } \\
\text { the luminal diameter increased } \\
\text { both in the control and in } \\
\text { the SAH group while wall } \\
\text { thickness was decreased in both } \\
\text { groups. }\end{array}$ & [3] \\
\hline $\begin{array}{c}\text { Study on wild type (WT) } \\
\text { and CBS-knock out (CBS-KO) } \\
\text { mouse vermis arterioles from } \\
\text { cerebellar slices }\end{array}$ & $\begin{array}{l}\text { Treatment on the cerebellar } \\
\text { slices either with } \\
\text { the HO-inhibitor ZnPP or } 30 \mu \mathrm{M} \\
\text { NaHS; studying the effect of } \\
\text { glibenclamide treatment }\end{array}$ & $\begin{array}{l}\text { In WT mice ZnPP elicited } \\
\text { vasorelaxation through blockade } \\
\text { of CO comparably to the effect } \\
\text { of NaHS. In CBS-KO mice, } \mathrm{ZnPP} \\
\text { treatment did not result in } \\
\text { vasodilation; the effect of NaHS } \\
\text { was more pronounced, but it } \\
\text { was abolished by glibenclamide }\end{array}$ & [48] \\
\hline
\end{tabular}

Another possibility in the investigation of the possible roles of hydrogen sulfide in living systems is the inhibition of the enzymes that are producing it. This method may also help to elucidate which enzyme is responsible for the $\mathrm{H}_{2} \mathrm{~S}$ production in a given tissue. Such experiments are summarized in Table 4.

There are further possible approaches which are not falling into the abovementioned two categories. Some of these are focusing on the importance of endogenous $\mathrm{H}_{2} \mathrm{~S}$-production in animals that lack one of the synthesizing enzymes $\left(\mathrm{CSE}^{-/-}\right.$or $\left.\mathrm{CBS}^{-/-}\right)$while others are using disease models or other vasoactive agents and focus on the plasma or tissue concentrations of hydrogen sulfide (Table 5). 
Table 3. In vivo investigations involving $\mathrm{H}_{2} \mathrm{~S}$ donor treatment.

\begin{tabular}{|c|c|c|c|}
\hline Study Type & Experimental Situations & Major Conclusions & Ref \\
\hline $\begin{array}{l}\text { Study on pial arteries } \\
\text { using cranial windows } \\
\text { on Wistar rats }\end{array}$ & $\begin{array}{l}\text { Effect of } 30 \mu \mathrm{M} \mathrm{NaHS} \text { on } \\
\text { the vascular tone given with } \\
\text { SNP or glibenclamide }\end{array}$ & $\begin{array}{l}\text { NaHS induced vasodilation; NaHS } \\
\text { and SNP produced greater vasodilation } \\
\text { together than alone; inhibition of NO } \\
\text { production or administration of } \\
\text { glibenclamide decreased } \\
\text { the vasodilatory effect of NaHS }\end{array}$ & [46] \\
\hline $\begin{array}{l}\text { Study on meningeal } \\
\text { arteries using cranial } \\
\text { windows on Wistar rats }\end{array}$ & $\begin{array}{c}\text { Effects of } 300 \mu \mathrm{M} \mathrm{Na} \mathrm{N}_{2} \mathrm{~S} \text { on } \\
\text { the meningeal blood flow; } \\
\text { Examinations on the role of } \\
\text { the CGRP pathway }\end{array}$ & $\begin{array}{l}\mathrm{Na}_{2} \mathrm{~S} \text { caused rapid increase in } \\
\text { the meningeal blood flow and in } \\
\text { the CGRP release; CGRP receptor or } \\
\text { TRPA1 channel antagonists abolished } \\
\text { the effect; } \\
\text { L-NMMA decreased the effect }\end{array}$ & [4] \\
\hline $\begin{array}{l}\text { Study on pig pial } \\
\text { arterioles using cranial } \\
\text { windows }\end{array}$ & $\begin{array}{l}\text { Topical application of } 10^{-6}-2 \times \\
10^{-4} \mathrm{H}_{2} \mathrm{~S} \text { with either } 1-7 \mathrm{mM} \\
\text { L-cysteine or glibenclamide }\end{array}$ & $\begin{array}{c}\mathrm{H}_{2} \mathrm{~S} \text { and L-cysteine dilated the arterioles } \\
\text { in a concentration-dependent manner, } \\
\text { glibenclamide blocked the effect- } \\
\text { L-cysteine increased the } \mathrm{H}_{2} \mathrm{~S} \text { level in } \\
\text { the CSF }\end{array}$ & [49] \\
\hline $\begin{array}{l}\text { Examination of tissue } \\
\text { samples after middle } \\
\text { cerebral artery occlusion } \\
\quad \text { in Wistar rats }\end{array}$ & $\begin{array}{l}\text { Effects of L-cysteine (2.5-5-10 } \\
\text { mmol/kg ip. or 0.25-1.0-2.5 } \\
\text { through intracerebroventricular } \\
\text { injection) or } 0.5 \mathrm{mmol} / \mathrm{kg} \text { AOAA } \\
\text { ip. on the outcome of stroke }\end{array}$ & $\begin{array}{l}\text { L-cysteine dose-dependently increased } \\
\text { the infarct volume by } 30 \% \\
\text { AOAA diminished the L-cys induced } \\
\text { the increase of post-stroke area }\end{array}$ & {$[58]$} \\
\hline
\end{tabular}

Table 4. Ex vivo and in vivo investigations involving inhibitors of $\mathrm{H}_{2} \mathrm{~S}$ producing enzymes.

\begin{tabular}{|c|c|c|c|}
\hline Study Type & Experimental Situations & Major Conclusions & Ref \\
\hline $\begin{array}{l}\text { Ex vivo wire myograph } \\
\text { study on middle cerebral } \\
\text { artery segments from } \\
\text { Sprague-Dawley rats }\end{array}$ & $\begin{array}{c}\text { Effects of } 0.1-10 \mathrm{mM} \text { L-cysteine } \\
\text { alone and with } 1 \mathrm{mM} \text { PAG or } 1 \\
\mathrm{mM} / 1 \text { AOAA on the vascular } \\
\text { tone }\end{array}$ & $\begin{array}{l}\text { PAG inhibited the L-cysteine induced } \\
\text { vasorelaxation, but AOAA had no effect }\end{array}$ & [56] \\
\hline $\begin{array}{l}\text { Ex vivo wire myograph } \\
\text { study on middle cerebral } \\
\text { artery segments of WT } \\
\text { and STZ-induced diabetic } \\
\text { Sprague-Dawley rats }\end{array}$ & $\begin{array}{l}\text { Examination of vascular tone } \\
\text { after }(10 \mu \mathrm{M}-100 \mathrm{mM}) \mathrm{L} \text {-cyteine } \\
\text { and } 20 \mathrm{mM} \text { PAG treatment }\end{array}$ & $\begin{array}{l}\text { The effect of L-cysteine was attenuated } \\
\text { by PAG both in the diabetic } \\
\text { and control group }\end{array}$ & [52] \\
\hline $\begin{array}{l}\text { In vivo carotid ligation study } \\
\text { on pial arteries of Wistar rats }\end{array}$ & $\begin{array}{l}\text { Effects of } 30 \mathrm{mM} \text { PAG on } \\
\text { the Ach-induced vasodilation }\end{array}$ & $\begin{array}{l}\text { PAG did not decrease Ach-induced } \\
\text { vasodilation in the large vessels, just in } \\
\text { the small pial arteries; } \\
\text { After ischemia, the effect of PAG did not } \\
\text { change significantly }\end{array}$ & [46] \\
\hline $\begin{array}{l}\text { In vivo study on meningeal } \\
\text { arteries of Wistar rats using } \\
\text { cranial windows }\end{array}$ & $\begin{array}{l}\text { Effects of } 2 \mathrm{mM} \text { oxamic acid } \\
\left(\mathrm{H}_{2} \mathrm{~S} \text { inhibitor) on the NO }\right. \\
\text { mediated vasodilation }\end{array}$ & $\begin{array}{c}\text { Oxamic acid reduced the blood flow } \\
\text { increase evoked by the NO donor DEA } \\
\text { NONOate }\end{array}$ & {$[4]$} \\
\hline $\begin{array}{l}\text { In vivo study on pig pial } \\
\text { arterioles using } \\
\text { cranial windows }\end{array}$ & $\begin{array}{c}\text { Topical application of L-cysteine } \\
\text { followed by } 10 \mathrm{mM} \text { PAG or } \\
\text { 1mM AOAA on } \\
\text { the cranial windows }\end{array}$ & $\begin{array}{l}\text { Hypercapnia increased the } \mathrm{H}_{2} \mathrm{~S} \text { level in } \\
\text { the CSF given before but not during } \\
\text { PAG treatment. } \\
\text { AOAA had no effect. }\end{array}$ & [49] \\
\hline
\end{tabular}


Table 5. Ex vivo and in vivo studies involving knock-out animals and disease models.

\begin{tabular}{|c|c|c|c|}
\hline Study Type & Experimental Situations & Major Conclusions & Ref \\
\hline $\begin{array}{l}\text { Ex vivo study on neonatal } \\
\text { mouse (WT, HO2-null } \\
\text { and CBS-null) vermis } \\
\text { arterioles using cerebellar } \\
\text { slices }\end{array}$ & Hypoxia & $\begin{array}{l}\text { hypoxia elicited vasodilation, the effect } \\
\text { was decreased both in HO-2-null } \\
\text { and CBS-null mice }\end{array}$ & [48] \\
\hline $\begin{array}{l}\text { Ex vivo wire myograph } \\
\text { study on basilar arteries of } \\
\text { WT and } \mathrm{CSE}^{-/-} \text {mice }\end{array}$ & $\begin{array}{l}\text { Effects of RhoA agonist LPA } \\
\text { and U46619 on vascular tone } \\
\text { Effects of the Rho-associated } \\
\text { protein kinase (ROCK) inhibitor } \\
\text { Y27632 on CSE }{ }^{-/-} \text {mice }\end{array}$ & $\begin{array}{l}\text { LPA and U46619 induced constriction, } \\
\text { which was more pronounced in } \\
\text { CSE }^{--} \text {mice; } \\
\text { in } \mathrm{CSE}^{-/-} \text {Y27632-induced relaxation } \\
\text { was decreased }\end{array}$ & [53] \\
\hline $\begin{array}{l}\text { In vivo examination of } \\
\text { mouse (WT, HO2-null } \\
\text { and CBS-null) cortical } \\
\text { precapillary arterioles by } \\
\text { two-photon intravital laser } \\
\text { scanning microscopy }\end{array}$ & Hypoxia with $10 \% \mathrm{O}_{2}$ & $\begin{array}{l}\text { Hypoxia elicited vasodilation, } \\
\text { which was decreased in HO-2-null } \\
\text { and attenuated in CBS-null mice }\end{array}$ & [48] \\
\hline $\begin{array}{l}\text { In vivo study on pig pial } \\
\text { arterioles using cranial } \\
\text { windows }\end{array}$ & $\begin{array}{l}\text { Hypercapnia with } 10 \% \mathrm{CO}_{2} \text { for } \\
\qquad 5 \mathrm{~min}\end{array}$ & $\mathrm{H}_{2} \mathrm{~S}$ concentration in the CSF increased & [49] \\
\hline $\begin{array}{l}\text { In vivo study on pig pial } \\
\text { arterioles using cranial } \\
\text { windows }\end{array}$ & $\begin{array}{c}\text { Effect of low }\left(10^{-12}-10^{-11}\right) \text { or } \\
\text { high dose }\left(10^{-8}\right) \text { endothelin-1, } \\
\text { given with glibenclamide }\left(\mathrm{K}_{\mathrm{ATP}}\right. \\
\text { inhibitor) and paxilline (BK Ca } \\
\text { inhibitor) }\end{array}$ & $\begin{array}{l}\text { Low level of ET-1 induced vasodilation, } \\
\text { which was attenuated after } \\
\text { glibenclamide and paxilline. High level } \\
\text { of ET-1 induced vasoconstriction, } \\
\text { unaffected by glibenclamide or paxilline }\end{array}$ & [60] \\
\hline $\begin{array}{l}\text { In vivo human study on } \\
\text { post-stroke patients }\end{array}$ & $\begin{array}{l}\text { Examination of the linkage } \\
\text { between serum cysteine levels } \\
\text { and the outcome of stroke }\end{array}$ & $\begin{array}{c}\text { Positive correlation between increased } \\
\text { serum cysteine levels and poor } \\
\text { clinical outcome }\end{array}$ & [58] \\
\hline
\end{tabular}

We summarize here some of the key messages from the tables and we also provide a versatile Excel table as a supplement to this article in which individual considerations can be taken into account and rearrangements of the publications can be made accordingly (Supplementary Table S1).

In pig pial arteries and rat middle cerebral arteries, the CSE-inhibitor propargylglycine (PAG) was proven to be effective in counteracting the vasodilator effects of $\mathrm{H}_{2} \mathrm{~S}$, while the aminooxyacetate (AOAA), which is used as CBS inhibitor, had no remarkable effect $[49,52,56]$. Therefore, the cerebral vasculature probably produces $\mathrm{H}_{2} \mathrm{~S}$ mainly by CSE. However, in neonatal mice cerebellar slices the constitutively produced $\mathrm{CO}$ inhibited the CBS dependent $\mathrm{H}_{2} \mathrm{~S}$ generation, and in hypoxic conditions (modeled by treatment with the $\mathrm{HO}$ inhibitor $\mathrm{ZnPP}$ ) the lowered $\mathrm{CO}$ level enabled increased $\mathrm{H}_{2} \mathrm{~S}$ production leading to vasodilation in which $\mathrm{K}_{\text {ATP }}$ channel activation played a role [48]. Still, the vasorelaxant effect of NaHS was more pronounced in $\mathrm{CBS}^{-/-}$mice compared to WT animals which indicates that a supersensitivity to $\mathrm{H}_{2} \mathrm{~S}$ is present after the depletion of endogenous $\mathrm{H}_{2} \mathrm{~S}$ [48]. In an experiment that involved pressure myograph examinations on rat cerebral arteries exogenous $\mathrm{NaHS}$ induced relaxation of the vessel segments [56]. Furthermore, other studies have also proved that NaHS induced vasorelaxation at higher concentrations on rat middle cerebral arteries $[51,52]$ and on basilar artery segments derived from mice as well [53]. NaHS induced dose-dependent relaxation in rat middle cerebral arteries, which was reduced by nifedipine (voltage-gated $\mathrm{Ca}^{2+}$-channel blocker) and inhibited by $50 \mathrm{mM} \mathrm{K}^{+}$also, but selective blockers of $\mathrm{K}_{\mathrm{ATP}}, \mathrm{K}_{\mathrm{Ca}}, \mathrm{K}_{\mathrm{V}}$ or $\mathrm{K}_{\mathrm{ir}}$ channels failed to repeat this effect [51]. However, in a study on mouse cerebral arterioles, the vasodilator effect of $\mathrm{H}_{2} \mathrm{~S}$ was absent in SUR2-null animals, supporting the role of $\mathrm{K}_{\mathrm{ATP}}$ channels in this species [54]. Although treatment with the non-specific $\mathrm{Cl}^{-}$channel and anion exchanger inhibitor 4,4'-Diisothiocyano-2,2'-stilbenedisulfonic acid (DIDS) caused a rightward shift in the NaHS concentration-response curve, results after using more selective blockers of $\mathrm{Cl}^{-}$channels, such as niflumic acid, and results with the use of $\mathrm{HCO}_{3}{ }^{-}$ free solution question the involvement of $\mathrm{Cl}^{-} / \mathrm{HCO}_{3}{ }^{-}$exchange in the effects of $\mathrm{H}_{2} \mathrm{~S}$. Thus, DIDS, which is known to be non-specific in its actions, probably alters some other action of NaHS [51]. In this 
study, the vasodilation caused by NaHS did not depend on the presence of intact endothel; therefore, $\mathrm{H}_{2} \mathrm{~S}$ was supposed to be mainly produced in the vascular smooth muscle layer [51].

It might be important to separately consider the several investigations that were focusing on the effects of $\mathrm{H}_{2} \mathrm{~S}$ in pigs. In newborn pigs, $\mathrm{H}_{2} \mathrm{~S}$ produced by CSE appeared to be a functionally significant vasodilator molecule on pial arterioles, and it also had a role in the hypercapnia-induced vasodilation [49]. Opening of the $\mathrm{K}_{\mathrm{ATP}}$ channels were found to be involved in the effect of NaHS in pig cerebral circulation [49,54]. Considering experiments that involved pressure myograph examinations on piglet cerebral arterioles, one can conclude that exogenous NaHS induced relaxation of these vessel segments $[54,55]$. In newborn pig pial arteries lower concentrations of endothelin-1 (ET-1) had vasodilatory effect through $\mathrm{CSE} / \mathrm{H}_{2} \mathrm{~S}$ while a vasoconstrictor effect occurred at higher concentrations and it was independent from the activity of endogenous $\mathrm{H}_{2} \mathrm{~S}$ synthesis [60]. Therefore, it is important to note that vasoconstrictor effects of $\mathrm{H}_{2} \mathrm{~S}$ were also described in the cerebrovascular circulation similarly to the systemic circulation [61]. In a study on rat basilar artery segments, NaHS induced vasoconstriction between $10^{-7}$ and $10^{-3.5} \mathrm{M}$ concentrations. Interestingly, the vasoconstrictor effect weakened at 10-3.5 $\mathrm{M}$ and $\mathrm{NaHS}$ had the greatest vasoconstrictor potential while $\mathrm{Na}_{2} \mathrm{~S}$ induced lesser constriction, while the slow-releasing donor GYY4137 had the minimal effect [50]. This NaHS induced constriction on basilar artery segments was enhanced by isoprenaline and forskolin therefore suggesting that $\mathrm{H}_{2} \mathrm{~S}$ exerted its effects through the cAMP/adenylyl cyclase pathway [50]. Moreover, this vasoconstriction was thought to take part in setting the normal vascular tone on the basilar arteries by counteracting the vasorelaxation by NO [50]. In the same study on human brain vascular smooth muscle cells (HBVSMCs), NaHS attenuated the increase of cAMP levels after isoprenaline treatment and the enhanced adenylyl cyclase activity after forskolin, strengthening further that $\mathrm{H}_{2} \mathrm{~S}$ acted through the modulation of the $\beta$-adrenergic receptor related pathways [50].

In addition to the abovementioned studies that were investigating the effects of hydrogen sulfide in models that do not involve disease conditions, there were several ones looking into the role of $\mathrm{H}_{2} \mathrm{~S}$ in the pathogenesis of cerebrovascular diseases. $\mathrm{H}_{2} \mathrm{~S}$ showed beneficial effects in a rat model of middle cerebral artery occlusion as hydrogen sulfide promoted angiogenesis, endothelial cell synthesis and migration, and also exerted neuroprotective effects after ischemia [57]. In a rat model of subarachnoid hemorrhage, NaHS lowered the vascular tone in cerebral vasospasm [3]. According to a study on rat pial arteries, after cerebral ischemia-reperfusion, the NO-mediated vasodilation is affected more severely than the $\mathrm{H}_{2} \mathrm{~S}$-induced mechanisms, therefore this latter pathway has important role under these circumstances [46]. Examination of acute stroke patients revealed positive correlation between the serum cysteine levels and the clinical outcome of stroke [58]. However, in rat middle cerebral arteries, administration of cysteine increased the infarct volume, and this effect was inhibited by aminooxyacetic acid (AOAA, a CBS inhibitor) [58]. Therefore, it is still under debate whether post-stroke exogenous hydrogen sulfide therapy would exert beneficial effects or if it would even aggravate the tissue damage.

\section{Potential Roles of $\mathrm{H}_{2} \mathrm{~S}$ in the Context of Cerebrovascular Tone}

Analyzing the literature presented in the tables, one can note that the cerebrovascular effect of $\mathrm{H}_{2} \mathrm{~S}$ that most investigations are indicating is a vasodilatory response. It is of interest though that the precontraction levels are very varied among the experiments and in some cases the $\mathrm{H}_{2} \mathrm{~S}$ related effects are even measured on the spontaneous tone of the used vessel [51,52]. Therefore, the concentration ranges where $\mathrm{H}_{2} \mathrm{~S}$ may act as a vasodilatory molecule are ranging from as low as $10 \mu \mathrm{M}$ to $1 \mathrm{mM}$. In this context the used $\mathrm{H}_{2} \mathrm{~S}$ donor is probably very important as well. Within the group of $\mathrm{H}_{2} \mathrm{~S}$ donors, fast- and slow-release compounds can be distinguished. Fast releasing donors are sulfide salts, like sodium hydrosulfide (NaHS) or sodium disulfide $\left(\mathrm{Na}_{2} \mathrm{~S}\right)$ [62] and an important limitation regarding their use can be derived from their name. These donors lead to extremely high levels of $\mathrm{H}_{2} \mathrm{~S}$ immediately after their administration and then the level decreases rapidly resulting in highly fluctuating $\mathrm{H}_{2} \mathrm{~S}$ concentrations [62]. The slow-releasing donors (GYY4137, and its further 
derivatives) provide a more reliable dosage and a more sustained level of $\mathrm{H}_{2} \mathrm{~S}$ during treatment $[63,64]$. Interestingly, only one study about the cerebrovascular effect of $\mathrm{H}_{2} \mathrm{~S}$ included measurements with GYY4137 and according to the results of this publication, GYY4137 had the smallest effect on vascular tone compared to the fast-releasing compounds $\mathrm{NaHS}$ and $\mathrm{Na}_{2} \mathrm{~S}$ [50]. It was suspected that the difference might relate to the abovementioned $\mathrm{H}_{2} \mathrm{~S}$-releasing properties of GYY4137 [50].

The vasodilatory response involves similar mechanisms to those main effects that are reported in the systemic circulation, namely, interference with potassium channels with the NO-pathway and with voltage dependent calcium channels [36]. In this context, it is important to realize that interstitial $\mathrm{K}^{+}$levels may be more variable in the cerebrovascular region than in the systemic circulation due to the neuronal action potential firing related $\mathrm{K}^{+}$efflux. As many types of potassium channels are thought to be involved in the effects of $\mathrm{H}_{2} \mathrm{~S}$, this difference is probably important when we consider the net effects of $\mathrm{H}_{2} \mathrm{~S}$ in the cerebrovascular system. It is also noteworthy that instead of the periadventitial adipose tissue [65] astrocytic endfeets are found here and a very tightly regulated neurovascular coupling is present. In some experiments, vasoconstriction was also indicated [50] and this could be potentially very important as the use of $\mathrm{H}_{2} \mathrm{~S}$ was implied in the therapy of stroke [66]. The mechanism of action here might be related to interference with NO production [61] or decreasing cAMP levels in smooth muscle cells [50]. As shear stress is important in physiological NO production, the potential vasoconctrictor effect of $\mathrm{H}_{2} \mathrm{~S}$ might be flow-dependent; therefore, complete understanding is not entirely possible with the most widely used wire myography methods. This might be a reason for the relatively few publications on the vasoconstrictor effects of $\mathrm{H}_{2} \mathrm{~S}$. That the flow and the vasoconstriction may be interrelated in the context of $\mathrm{H}_{2} \mathrm{~S}$ is supported by our yet unpublished observations as well where we detected vasoconstriction to $1 \mathrm{mM}$ of NaHS in vessel areas where flow was present while observing vasodilation where no flow occurred (Figure 1). This was achieved by an unplanned constellation during our pressure myography measurements in which constant pressure was usually generated by a pump that pushed our Krebs solution into the vessel only from the left side and the right side was closed down. In normal circumstances, this led to a constant pressure of $50 \mathrm{mmHg}$ in the vessel segment without flow. However, when a supposedly ligated side branch remained open in between the cannulated rat anterior cerebral artery segment, flow occurred in one part of our segment but no flow on the other side of the leaking side branch.

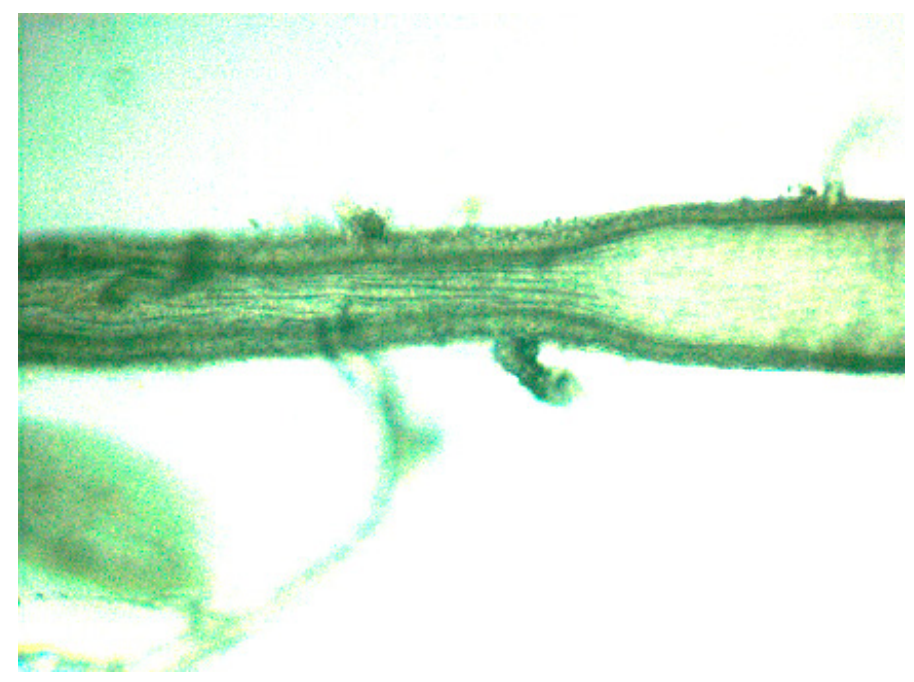

Figure 1. Effect of $1 \mathrm{mM}$ of NaHS on rat anterior cerebral artery segment precontracted with $3 \mu \mathrm{M}$ $\mathrm{U} 46619$ on a pressure myograph setup at $50 \mathrm{mmHg}$. The side branch in the middle was leaking and therefore flow occurred in the left part of the segment while no flow was present on the right which led to separate effects, namely, vasoconstriction where flow was present and vasodilation where no flow occurred. 
Based on the analyzed experiments and the abovementioned considerations and reconsidering the local factors involved in the cerebrovascular tone (myogenic, flow or shear mediated and metabolic responses), it seems probable that $\mathrm{H}_{2} \mathrm{~S}$ may have a role mostly in the metabolic regulation especially in the coupling of oxygen supply to the needs of neurons either via CO dependent CBS inhibition [48] or via $\mathrm{CO}_{2}$ dependent $\mathrm{pH}$ changes that influence $\mathrm{CSE}$ activity [49]. Interestingly, $\mathrm{H}_{2} \mathrm{~S}$ was already implicated in both oxygen dependent vasoconstriction and vasodilation in other circulatory regions [67]. Still, the complex interactions with the NO system [47] are far from being understood, especially in the context of the cerebral circulation, therefore $\mathrm{H}_{2} \mathrm{~S}$ may have an influence on the flow mediated regulation as well, which is supported by our own abovementioned observation.

\section{Conclusions}

Hydrogen sulfide definitely has the capability to alter the tone of cerebrovascular smooth muscle and its effects are highly dependent on such circumstances that are highly variable in the cerebral circulation. The actual myogenic tone, the flow mediated production of $\mathrm{NO}$, the actual $\mathrm{PaCO}_{2}$ and $\mathrm{PaO}_{2}$ levels are all involved in a complex equation regarding the net effect of $\mathrm{H}_{2} \mathrm{~S}$. The pleiotropic nature of its mechanisms of actions and their dose- and time-dependency further complicate the situation. Deciphering this equation is highly difficult and certainly necessitates further studies with more and more refined experimental tools but the clinical importance of cerebrovascular diseases definitely warrants such efforts.

Supplementary Materials: The following is available online at http://www.mdpi.com/2218-273X/10/12/1685/s1, Table S1: Summary of investigations into the role of $\mathrm{H}_{2} \mathrm{~S}$ in cerebrovascular circulation.

Author Contributions: These authors contributed equally to this work. All authors have read and agreed to the published version of the manuscript.

Funding: This work was supported by the Clinical Research Fellowship to E. D. by Semmelweis University.

Acknowledgments: The authors thank Gy. Nádasy for the technical help with the pressure myograph experiments.

Conflicts of Interest: The authors declare no conflict of interest.

\section{References}

1. WHO Organization. The Top 10 Causes of Death. Available online: https://www.who.int/news-room/factsheets/detail/the-top-10-causes-of-death (accessed on 17 October 2020).

2. Global Burden of Disease Collaborators. Global, regional, and national burden of stroke, 1990-2016: A systematic analysis for the Global Burden of Disease Study 2016. Lancet Neurol. 2019, 18, 439-458. [CrossRef]

3. Emmez, H.; Borcek, A.O.; Gonul, I.I.; Belen, H.B.; Solaroglu, I.; Baykaner, M.K. The Effect of Hydrogen Sulphide on Experimental Cerebral Vasospasm. Turk. Neurosurg. 2017, 27, 374-379. [CrossRef] [PubMed]

4. Dux, M.; Will, C.; Vogler, B.; Filipovic, M.R.; Messlinger, K. Meningeal blood flow is controlled by H2 S-NO crosstalk activating a HNO-TRPA1-CGRP signalling pathway. Br. J. Pharmacol. 2016, 173, 431-445. [CrossRef] [PubMed]

5. Hoffmann, J.; Baca, S.M.; Akerman, S. Neurovascular mechanisms of migraine and cluster headache. J. Cereb. Blood Flow Metab. 2019, 39, 573-594. [CrossRef] [PubMed]

6. Chin, J.H.; Vora, N. The global burden of neurologic diseases. Neurology 2014, 83, 349-351. [CrossRef]

7. Hamner, J.W.; Tan, C.O. Relative contributions of sympathetic, cholinergic, and myogenic mechanisms to cerebral autoregulation. Stroke 2014, 45, 1771-1777. [CrossRef]

8. Ainslie, P.N.; Brassard, P. Why is the neural control of cerebral autoregulation so controversial? F1000prime Rep. 2014, 6. [CrossRef]

9. Peterson, E.C.; Wang, Z.; Britz, G. Regulation of cerebral blood flow. Int. J. Vasc. Med. 2011, 2011, 823525. [CrossRef]

10. Halvorson, B.; Frisbee, J. Cerebral Vascular Tone Regulation: Integration and Impact of Disease. In Microcirculation; IntechOpen: London, UK, 2020.

11. Koller, A.; Toth, P. Contribution of flow-dependent vasomotor mechanisms to the autoregulation of cerebral blood flow. J. Vasc. Res. 2012, 49, 375-389. [CrossRef] 
12. Meng, L.; Gelb, A.W. Regulation of cerebral autoregulation by carbon dioxide. Anesthesiology 2015, 122, 196-205. [CrossRef]

13. Cipolla, M.J. Control of cerebral blood flow. In The Cerebral Circulation; Morgan \& Claypool Life Sciences: San Rafael, CA, USA, 2009.

14. Howarth, C. The contribution of astrocytes to the regulation of cerebral blood flow. Front. Neurosci. 2014, 8, 103. [CrossRef] [PubMed]

15. Hoiland, R.L.; Caldwell, H.G.; Howe, C.A.; Nowak-Fluck, D.; Stacey, B.S.; Bailey, D.M.; Paton, J.F.R.; Green, D.J.; Sekhon, M.S.; Macleod, D.B.; et al. Nitric oxide is fundamental to neurovascular coupling in humans. J. Physiol. 2020. [CrossRef] [PubMed]

16. Moncada, S.; Higgs, E.A. The discovery of nitric oxide and its role in vascular biology. Br. J. Pharmacol. 2006, 147, S193-S201. [CrossRef] [PubMed]

17. Toda, N.; Ayajiki, K.; Okamura, T. Cerebral blood flow regulation by nitric oxide: Recent advances. Pharmacol. Rev. 2009, 61, 62-97. [CrossRef]

18. Qi, M.; Hang, C.; Zhu, L.; Shi, J. Involvement of endothelial-derived relaxing factors in the regulation of cerebral blood flow. Neurol. Sci. 2011, 32, 551-557. [CrossRef]

19. Cholet, N.; Bonvento, G.; Seylaz, J. Effect of neuronal NO synthase inhibition on the cerebral vasodilatory response to somatosensory stimulation. Brain Res. 1996, 708, 197-200. [CrossRef]

20. Brian, J.E., Jr.; Heistad, D.D.; Faraci, F.M. Effect of carbon monoxide on rabbit cerebral arteries. Stroke 1994, 25, 639-643. [CrossRef]

21. Leffler, C.W.; Nasjletti, A.; Yu, C.; Johnson, R.A.; Fedinec, A.L.; Walker, N. Carbon monoxide and cerebral microvascular tone in newborn pigs. Am. J. Physiol. 1999, 276, H1641-H1646. [CrossRef]

22. Leffler, C.W.; Parfenova, H.; Jaggar, J.H. Carbon monoxide as an endogenous vascular modulator. Am. J. Physiol. Heart Circ. Physiol. 2011, 301, H1-H11. [CrossRef]

23. Jaggar, J.H.; Leffler, C.W.; Cheranov, S.Y.; Tcheranova, D.; E, S.; Cheng, X. Carbon monoxide dilates cerebral arterioles by enhancing the coupling of $\mathrm{Ca} 2+$ sparks to Ca2+-activated K+ channels. Circ. Res. 2002, 91, 610-617. [CrossRef]

24. Li, A.; Xi, Q.; Umstot, E.S.; Bellner, L.; Schwartzman, M.L.; Jaggar, J.H.; Leffler, C.W. Astrocyte-derived CO is a diffusible messenger that mediates glutamate-induced cerebral arteriolar dilation by activating smooth muscle Cell KCa channels. Circ. Res. 2008, 102, 234-241. [CrossRef] [PubMed]

25. Xi, Q.; Umstot, E.; Zhao, G.; Narayanan, D.; Leffler, C.W.; Jaggar, J.H. Glutamate regulates Ca2+ signals in smooth muscle cells of newborn piglet brain slice arterioles through astrocyte- and heme oxygenase-dependent mechanisms. Am. J. Physiol. Heart Circ. Physiol. 2010, 298, H562-H569. [CrossRef] [PubMed]

26. Ishikawa, M.; Kajimura, M.; Adachi, T.; Maruyama, K.; Makino, N.; Goda, N.; Yamaguchi, T.; Sekizuka, E.; Suematsu, M. Carbon monoxide from heme oxygenase-2 Is a tonic regulator against NO-dependent vasodilatation in the adult rat cerebral microcirculation. Circ. Res. 2005, 97, e104-e114. [CrossRef]

27. Lacza, Z.; Puskar, M.; Kis, B.; Perciaccante, J.V.; Miller, A.W.; Busija, D.W. Hydrogen peroxide acts as an EDHF in the piglet pial vasculature in response to bradykinin. Am. J. Physiol. Heart Circ. Physiol. 2002, 283, H406-H411. [CrossRef] [PubMed]

28. Eckman, D.M.; Nelson, M.T. Potassium ions as vasodilators: Role of inward rectifier potassium channels. Am. Heart Assoc. 2001. [CrossRef]

29. McNeish, A.J.; Dora, K.A.; Garland, C.J. Possible role for $\mathrm{K}+$ in endothelium-derived hyperpolarizing factor-linked dilatation in rat middle cerebral artery. Stroke 2005, 36, 1526-1532. [CrossRef]

30. Iida, Y.; Katusic, Z.S. Mechanisms of cerebral arterial relaxations to hydrogen peroxide. Stroke 2000, 31, 2224-2230. [CrossRef]

31. Wang, R. Physiological implications of hydrogen sulfide: A whiff exploration that blossomed. Physiol. Rev. 2012, 92, 791-896. [CrossRef]

32. Li, L.; Rose, P.; Moore, P.K. Hydrogen sulfide and cell signaling. Annu. Rev. Pharmacol. Toxicol. 2011, 51, $169-187$. [CrossRef]

33. Wang, Z.; Liu, D.X.; Wang, F.W.; Zhang, Q.; Du, Z.X.; Zhan, J.M.; Yuan, Q.H.; Ling, E.A.; Hao, A.J. L-Cysteine promotes the proliferation and differentiation of neural stem cells via the $\mathrm{CBS} / \mathrm{H}(2) \mathrm{S}$ pathway. Neuroscience 2013, 237, 106-117. [CrossRef]

34. Kimura, H. Hydrogen sulfide: Its production and functions. Exp. Physiol. 2011, 96, 833-835. [CrossRef] 
35. Beard, R.S., Jr.; Bearden, S.E. Vascular complications of cystathionine beta-synthase deficiency: Future directions for homocysteine-to-hydrogen sulfide research. Am. J. Physiol. Heart Circ. Physiol. 2011, 300, H13-H26. [CrossRef] [PubMed]

36. Dongo, E.; Beliczai-Marosi, G.; Dybvig, A.S.; Kiss, L. The mechanism of action and role of hydrogen sulfide in the control of vascular tone. Nitric Oxide 2018, 81, 75-87. [CrossRef] [PubMed]

37. Shibuya, N.; Koike, S.; Tanaka, M.; Ishigami-Yuasa, M.; Kimura, Y.; Ogasawara, Y.; Fukui, K.; Nagahara, N.; Kimura, H. A novel pathway for the production of hydrogen sulfide from D-cysteine in mammalian cells. Nat. Commun. 2013, 4, 1366. [CrossRef] [PubMed]

38. Nagy, P.; Palinkas, Z.; Nagy, A.; Budai, B.; Toth, I.; Vasas, A. Chemical aspects of hydrogen sulfide measurements in physiological samples. Biochim. Biophys. Acta 2014, 1840, 876-891. [CrossRef] [PubMed]

39. Kiss, L.; Deitch, E.A.; Szabo, C. Hydrogen sulfide decreases adenosine triphosphate levels in aortic rings and leads to vasorelaxation via metabolic inhibition. Life Sci. 2008, 83, 589-594. [CrossRef]

40. Coletta, C.; Papapetropoulos, A.; Erdelyi, K.; Olah, G.; Modis, K.; Panopoulos, P.; Asimakopoulou, A.; Gero, D.; Sharina, I.; Martin, E.; et al. Hydrogen sulfide and nitric oxide are mutually dependent in the regulation of angiogenesis and endothelium-dependent vasorelaxation. Proc. Natl. Acad. Sci. USA 2012, 109, 9161-9166. [CrossRef]

41. Olson, K.R. Vascular actions of hydrogen sulfide in nonmammalian vertebrates. Antioxid. Redox Signal. 2005, 7, 804-812. [CrossRef]

42. Koenitzer, J.R.; Isbell, T.S.; Patel, H.D.; Benavides, G.A.; Dickinson, D.A.; Patel, R.P.; Darley-Usmar, V.M.; Lancaster, J.R., Jr.; Doeller, J.E.; Kraus, D.W. Hydrogen sulfide mediates vasoactivity in an O2-dependent manner. Am. J. Physiol. Heart Circ. Physiol. 2007, 292, H1953-H1960. [CrossRef]

43. Zhao, W.; Wang, R. H(2)S-induced vasorelaxation and underlying cellular and molecular mechanisms. Am. J. Physiol. Heart Circ. Physiol. 2002, 283, H474-H480. [CrossRef]

44. Dongo, E.; Hornyak, I.; Benko, Z.; Kiss, L. The cardioprotective potential of hydrogen sulfide in myocardial ischemia/reperfusion injury (review). Acta Physiol. Hung. 2011, 98, 369-381. [CrossRef] [PubMed]

45. Filipovic, M.R. Persulfidation (S-sulfhydration) and H2S. Handb. Exp. Pharmacol. 2015, 230, 29-59. [CrossRef] [PubMed]

46. Lobov, G.I.; Sokolova, I.B.; Gorshkova, O.P.; Shvetsova, M.E.; Dvoretskii, D.P. Contribution of Hydrogen Sulfide to Dilation of Rat Cerebral Arteries after Ischemia/Reperfusion Injury. Bull. Exp. Biol. Med. 2020, 168, 597-601. [CrossRef] [PubMed]

47. Cortese-Krott, M.M.; Kuhnle, G.G.; Dyson, A.; Fernandez, B.O.; Grman, M.; DuMond, J.F.; Barrow, M.P.; McLeod, G.; Nakagawa, H.; Ondrias, K.; et al. Key bioactive reaction products of the NO/H2S interaction are S/N-hybrid species, polysulfides, and nitroxyl. Proc. Natl. Acad. Sci. USA 2015, 112, E4651-E4660. [CrossRef]

48. Morikawa, T.; Kajimura, M.; Nakamura, T.; Hishiki, T.; Nakanishi, T.; Yukutake, Y.; Nagahata, Y.; Ishikawa, M.; Hattori, K.; Takenouchi, T.; et al. Hypoxic regulation of the cerebral microcirculation is mediated by a carbon monoxide-sensitive hydrogen sulfide pathway. Proc. Natl. Acad. Sci. USA 2012, 109, 1293-1298. [CrossRef]

49. Leffler, C.W.; Parfenova, H.; Basuroy, S.; Jaggar, J.H.; Umstot, E.S.; Fedinec, A.L. Hydrogen sulfide and cerebral microvascular tone in newborn pigs. Am. J. Physiol. Heart Circ. Physiol. 2011, 300, H440-H447. [CrossRef]

50. Li, S.; Ping, N.N.; Cao, L.; Mi, Y.N.; Cao, Y.X. H2S induces vasoconstriction of rat cerebral arteries via cAMP/adenylyl cyclase pathway. Toxicol. Appl. Pharmacol. 2015, 289, 389-396. [CrossRef]

51. Streeter, E.; Hart, J.; Badoer, E. An investigation of the mechanisms of hydrogen sulfide-induced vasorelaxation in rat middle cerebral arteries. Naunyn Schmiedebergs Arch. Pharmacol. 2012, 385, 991-1002. [CrossRef]

52. Streeter, E.Y.; Badoer, E.; Woodman, O.L.; Hart, J.L. Effect of type 1 diabetes on the production and vasoactivity of hydrogen sulfide in rat middle cerebral arteries. Physiol. Rep. 2013, 1, e00111. [CrossRef]

53. Wen, J.Y.; Gao, S.S.; Chen, F.L.; Chen, S.; Wang, M.; Chen, Z.W. Role of CSE-Produced H2S on Cerebrovascular Relaxation via RhoA-ROCK Inhibition and Cerebral Ischemia-Reperfusion Injury in Mice. ACS Chem. Neurosci. 2019, 10, 1565-1574. [CrossRef]

54. Liang, G.H.; Adebiyi, A.; Leo, M.D.; McNally, E.M.; Leffler, C.W.; Jaggar, J.H. Hydrogen sulfide dilates cerebral arterioles by activating smooth muscle cell plasma membrane KATP channels. Am. J. Physiol. Heart Circ. Physiol. 2011, 300, H2088-H2095. [CrossRef]

55. Liang, G.H.; Xi, Q.; Leffler, C.W.; Jaggar, J.H. Hydrogen sulfide activates Ca(2)(+) sparks to induce cerebral arteriole dilatation. J. Physiol. 2012, 590, 2709-2720. [CrossRef] [PubMed] 
56. Tian, X.Y.; Wong, W.T.; Sayed, N.; Luo, J.; Tsang, S.Y.; Bian, Z.X.; Lu, Y.; Cheang, W.S.; Yao, X.; Chen, Z.Y.; et al. NaHS relaxes rat cerebral artery in vitro via inhibition of 1-type voltage-sensitive Ca2+ channel. Pharmacol. Res. 2012, 65, 239-246. [CrossRef] [PubMed]

57. Jang, H.; Oh, M.Y.; Kim, Y.J.; Choi, I.Y.; Yang, H.S.; Ryu, W.S.; Lee, S.H.; Yoon, B.W. Hydrogen sulfide treatment induces angiogenesis after cerebral ischemia. J. Neurosci. Res. 2014, 92, 1520-1528. [CrossRef] [PubMed]

58. Wong, P.T.; Qu, K.; Chimon, G.N.; Seah, A.B.; Chang, H.M.; Wong, M.C.; Ng, Y.K.; Rumpel, H.; Halliwell, B.; Chen, C.P. High plasma cyst(e)ine level may indicate poor clinical outcome in patients with acute stroke: Possible involvement of hydrogen sulfide. J. Neuropathol. Exp. Neurol. 2006, 65, 109-115. [CrossRef] [PubMed]

59. Brenner, M.; Benavides, S.; Mahon, S.B.; Lee, J.; Yoon, D.; Mukai, D.; Viseroi, M.; Chan, A.; Jiang, J.; Narula, N.; et al. The vitamin B12 analog cobinamide is an effective hydrogen sulfide antidote in a lethal rabbit model. Clin. Toxicol. 2014, 52, 490-497. [CrossRef]

60. Patel, S.; Fedinec, A.L.; Liu, J.; Weiss, M.A.; Pourcyrous, M.; Harsono, M.; Parfenova, H.; Leffler, C.W. H2S mediates the vasodilator effect of endothelin-1 in the cerebral circulation. Am. J. Physiol. Heart Circ. Physiol. 2018, 315, H1759-H1764. [CrossRef]

61. Chai, Q.; Lu, T.; Wang, X.L.; Lee, H.C. Hydrogen sulfide impairs shear stress-induced vasodilation in mouse coronary arteries. Pflugers Arch. 2015, 467, 329-340. [CrossRef]

62. Powell, C.R.; Dillon, K.M.; Matson, J.B. A review of hydrogen sulfide (H2S) donors: Chemistry and potential therapeutic applications. Biochem. Pharmacol. 2018, 149, 110-123. [CrossRef]

63. Kang, J.; Neill, D.L.; Xian, M. Phosphonothioate-Based Hydrogen Sulfide Releasing Reagents: Chemistry and Biological Applications. Front. Pharmacol 2017, 8, 457. [CrossRef]

64. Li, L.; Whiteman, M.; Guan, Y.Y.; Neo, K.L.; Cheng, Y.; Lee, S.W.; Zhao, Y.; Baskar, R.; Tan, C.H.; Moore, P.K. Characterization of a novel, water-soluble hydrogen sulfide-releasing molecule (GYY4137): New insights into the biology of hydrogen sulfide. Circulation 2008, 117, 2351-2360. [CrossRef] [PubMed]

65. Kohn, C.; Schleifenbaum, J.; Szijarto, I.A.; Marko, L.; Dubrovska, G.; Huang, Y.; Gollasch, M. Differential effects of cystathionine-gamma-lyase-dependent vasodilatory $\mathrm{H} 2 \mathrm{~S}$ in periadventitial vasoregulation of rat and mouse aortas. PLoS ONE 2012, 7, e41951. [CrossRef] [PubMed]

66. Jia, J.; Li, J.; Cheng, J. H2S-based therapies for ischaemic stroke: Opportunities and challenges. Stroke Vasc. Neurol. 2019, 4, 63-66. [CrossRef] [PubMed]

67. Olson, K.R.; Dombkowski, R.A.; Russell, M.J.; Doellman, M.M.; Head, S.K.; Whitfield, N.L.; Madden, J.A. Hydrogen sulfide as an oxygen sensor/transducer in vertebrate hypoxic vasoconstriction and hypoxic vasodilation. J. Exp. Biol. 2006, 209, 4011-4023. [CrossRef]

Publisher's Note: MDPI stays neutral with regard to jurisdictional claims in published maps and institutional affiliations.

(C) 2020 by the authors. Licensee MDPI, Basel, Switzerland. This article is an open access article distributed under the terms and conditions of the Creative Commons Attribution (CC BY) license (http://creativecommons.org/licenses/by/4.0/). 